\title{
Effects of Dietary Carbohydrases on Growth Performance, Nutrient Digestibility and Blood Characteristics in Finishing Pigs
}

\author{
Keun Hyoung Kim, Jin Ho Cho and In Ho Kim* \\ Department of Animal Resources \& Science, Dankook University, No. 29 Anseodong, Cheonan, Choongnam 330-714, \\ South Korea
}

\begin{abstract}
The objective of this study was to assess the effects of dietary carbohydrases on growth performance, nutrient digestibility and blood characteristics in finishing pigs. A total of 90 pigs [(Landrace $\times$ Yorkshire $) \times$ Duroc] (initial $\mathrm{BW}=56.15 \pm 1.26 \mathrm{~kg})$ were used for a $35 \mathrm{~d}$ feeding trial. The dietary treatments included: 1) CON (control diet), 2) MIX (CON + mixture with a-galactosidase and $\beta$-mannanase $0.05 \%)$ and 3) MAN $(\mathrm{CON}+\beta$-mannanase $0.05 \%)$. There were six replications per treatment with five pigs per pen. The average daily gain (ADG) in MIX was higher than in $\mathrm{CON}(p<0.05)$. No significant differences were noted in the average daily feed intake (ADFI) and feed efficiency (G:F) among dietary treatments $(p>0.05)$. Apparent total tract digestibility (ATTD) of dry matter $(\mathrm{DM})$ and energy $(\mathrm{E})$ in MIX increased $(p<0.05)$ relative to CON and MAN. The ATTD of nitrogen $(\mathrm{N})$ in MIX was higher $(p<0.05)$ than in CON. No differences in red blood cells (RBC), white blood cells (WBC), lymphocytes and IgG concentrations were observed among dietary treatments $(p>0.05)$. In conclusion, the addition of the mixture of carbohydrases $(a-$ galactosidase and $\beta$-mannanase $0.05 \%$ ) increased ADG and nutrient digestibility in finishing pigs.
\end{abstract}

(Key words : Carbohydrases, Finishing pig, Nutrient digestibility)

\section{INTRODUCTION}

NSPs (non starch polysaccharide) included $\beta$-glucan, xylose, mannan, cellulose, and pectin, which cannot be digested by poultry or swine. Additionally, these NSPs increase the viscosity, which prevents other nutrients from being utilized by the animals (Burnett, 1966; White, 1981; McCracken et al., 2001) and reduces growth performance (Blackburn and Johnson, 1981; Rainbird et al., 1984; Edwards et al., 1988).

Common cereals harbor high proportions of partially soluble dietary cell wall polysaccharides, which primarily consist of mixed-linked (1-3), (1-4)- $\beta$-D-glucan ( $\beta$-glucan) in barley and oats and arabinoxylans in wheat, rye, and triticale (Bach Knudsen, 1997). $\beta$-glucans and arabinoxylans function by increasing gastrointestinal viscosity, and their partial destruction by specific enzyme supplementation may enhance the nutritional value of the diet(Chesson, 1987; Bedford, 1995).

Soybean meal is one of the most frequently employed sources of protein, containing 22.7\% NSP (Chesson, 1987), and the cell walls of plant sources consist of more than $15 \%$ NSP. NSP in the cell wall may prevent the digestion and absorption of nutrients (Omobebigun et al., 2004). The principal NSP in the cell walls of plants is hemicellulose, primarily xylose and mannan. Compounds preventing digestion include trypsin inhibitors that interfere with protein digestion, in addition to non-starch polysaccharides such as arabinoxylans, pectins, $\beta$-glucans in corn and soybean meal (Hong and Kim, 2001). These substances reduce digestion and absorption in the intestine, which may induce increases in the feed intake and feed cost of the swine industry.

Non starch polysaccharide (NSP) depolymerizing carbodrase enzymes may exploit several modes of action including partial hydrolysis of NSP, reductions in digesta viscosity, and the rupture of NSP-containing cell walls, thereby rendering the encapsulated nutrients available for digestion(Simon, 1998). Other effects include shifts in the population and activity of the microflora as a consequence of enzyme supplementation (Vahjen et al., 1998).

Therefore, the present study was conducted to evaluate the effects of dietary carbohydrases on growth performance, nutrient digestibility, and blood characteristics in finishing pigs.

* Corresponding author: In Ho Kim, Department of Animal Resource \& Science, Dankook University No. 29 Anseodong, Cheonan, Choongnam, 330-714, South Korea. Tel: 82-41-550-3652, Fax: 82-41-565-2949, E-mail: inhokim@dankook.ac.kr 
Kim et al.; Carbohydrases in Early Finishing Pigs

\section{MATERIALS AND METHODS}

\section{Experimental design, animals, and diets}

A total of 90 crossbred pigs [(Landrace $\times$ Yorkshire $) \times$ Duroc] with an initial body weight (BW) of $56.15 \pm 1.26 \mathrm{~kg}$ were used in a $35 \mathrm{~d}$ trial. At the beginning of the experiment, the pigs were allotted to one of five dietary treatment groups on the basis of initial body weight (IBW) in accordance with a randomized complete block design. There were six replication pens per treatment, with five pigs per pen. The dietary treatments included: 1) CON (control diet), 2) $\operatorname{MIX}(\mathrm{CON}+$ Mixture with a-galactosidase and $\beta$ mannanase $0.05 \%$ ) and 3$) \mathrm{MAN}(\mathrm{CON}+\beta$-mannanase $0.05 \%)$. The diets employed in this experiment fulfilled or exceeded the NRC (1998) recommendations for all nutrients, regardless of treatment (Table 1). Throughout the experimental period, the pigs were permitted ad libitum access to feed and water using a self-feeder and nipple water.

\section{Sampling and measurements}

For the growth assay, BW and feed intake were measured initially to calculate the $\mathrm{ADG}, \mathrm{ADFI}$, and $\mathrm{G}: \mathrm{F}$ ratio at $35 \mathrm{~d}$. Chromic oxide $(0.20 \%)$ was added as an inert indicator to calculate the apparent digestibility of DM, N and energy. After the pigs were fed diets containing the indicator for 7 days, fresh fecal grab samples were obtained from each pen. The fecal samples were then dried at $70^{\circ} \mathrm{C}$ for $72 \mathrm{~h}$, after which they were finely ground to be able to pass through a $1-\mathrm{mm}$ screen. All feed and feces samples were then frozen at $-20^{\circ} \mathrm{C}$ until further analysis. The DM, N and energy digestibility were determined in accordance with the methods established by the Association of Official Analytical Chemists (1998). Chromium levels were determined by UV Absorption Spectrophotometry (Shimadzu, UV-1201, Japan) and the apparent digestibility of DM, N and energy were calculated using indirect methods. The gross energy in the feed and feces was determined using a calorimeter (Mode 1241, Parr Instrument Co., USA) according to the method described by Williams et al. (1962).

For the blood characteristics assay, blood samples were collected from ten pigs in each treatment group via jugular venipuncture at the beginning of the experiment and again on $\mathrm{d}$ 35. At each collection time, blood samples were collected into both a nonheparinized and a $\mathrm{K}_{3}$ EDTA vacuum
Table 1. Composition of basal diet (as-fed basis)

\begin{tabular}{lc}
\hline Ingredients, \% & \\
\hline \hline Corn & 55.61 \\
Soybean meal & 31.03 \\
Rapeseed meal & 1.60 \\
Rice bran & 1.50 \\
Tallow & 4.35 \\
Molasses & 3.10 \\
Dicalcium phosphate & 1.18 \\
Limestone & 0.79 \\
Salt & 0.20 \\
L-lysine (74\%) & 0.34 \\
Vitamin premix ${ }^{1)}$ & 0.20 \\
Trace mineral premix ${ }^{2)}$ & 0.10 \\
Total & 100.00 \\
\hline Calculated composition & \\
DE, kcal/kg & 3,400 \\
Crude protein, \% & 17.00 \\
Lysine, \% & 0.98 \\
Calcium, \% & 0.75 \\
Phosphorus, \% & 0.62 \\
NSP, \% D & 6.94 \\
\hline
\end{tabular}

${ }^{1)}$ Provided per $\mathrm{kg}$ of complete diet: 6,500 IU vitamin A, $950 \mathrm{IU}$ vitamin $\mathrm{D}_{3}, 27 \mathrm{IU}$ vitamin $\mathrm{E}, 2.0 \mathrm{mg}$ vitamin $\mathrm{K}_{3}, 3.6 \mathrm{mg}$ vitamin $\mathrm{B}_{2}, 1.3 \mathrm{mg}$ vitamin $\mathrm{B}_{6}, 15 \mathrm{mg}$ pantothenic acid, $26.0 \mathrm{mg}$ niacin and $0.03 \mathrm{mg}$ biotin.

${ }^{2)}$ Provided per $\mathrm{kg}$ of complete diet: $50 \mathrm{mg} \mathrm{Mn}$ (as manganese oxide), $70 \mathrm{mg} \mathrm{Zn}$ (as zinc oxide), $54 \mathrm{mg} \mathrm{Cu}$ (as copper sulfate), $0.5 \mathrm{mg} \mathrm{I}$ (as calcium iodate), $0.5 \mathrm{mg} \mathrm{Co}$ and $0.25 \mathrm{mg} \mathrm{Se}$.

tube (Becton Dickinson Vacutainer Systems, Franklin Lakes, NJ) to enable evaluation of the serum and whole blood, respectively. The white blood cell (WBC), red blood cell (RBC), and lymphocyte counts were determined using an automatic blood analyzer (ADVIA 120, Bayer, NY). The immunoglobulin $\mathrm{G}(\mathrm{IgG})$ was analyzed using nephelometry (Dade Behring, Marburg, Germany).

\section{Statistical analysis}

In this experiment, data were analyzed via ANOVA using the GLM procedure described by SAS (SAS Institute, 1996), with the pen defined as the experimental unit. Differences among all treatments were separated via Duncan's multiple range test. The results were expressed as the least-square 
means and SEM. Probability values of less than 0.05 were considered significant.

\section{RESULTS AND DISCUSSION}

\section{Growth performance}

Table 2 shows the effects of dietary carbohydrase on growth performance in early finishing pigs. The average daily gain (ADG) in the MIX treatment was higher than that of the CON group $(p<0.05)$. No significant differences in the average daily feed intake (ADFI) and $G: F$ ratio were observed among dietary treatments $(p>0.05)$.

The increased weight gain in the high-NSP diets was most likely induced by a higher gut fill (Jørgensen et al., 1996) and by increased internal organ weight (Kass et al., 1980; Jørgensen et al., 1996; McDonald et al., 1999). The effects of flaxseed (FS) on overall growth performance in the current study are consistent with those reported in a previous study conducted by Van Kessel et al. (2006). In that study, piglets fed on a wheat-soybean meal basal diet or a basal diet amended witheither 5 or $10 \%$ ground FS showedsimilar growth performance. These findings are consistent with the results of studies conducted by Högberg and Lindberg (2004) and Zijlstra et al. (2004), who reported that enzyme supplementation exerted no consistent effects on growth performance variables. This is surprising since a previous study conducted by the same laboratory using the same multi carbohydrase enzyme demonstrated consistent improvements in the growth performance of piglets fed on wheat- and soybean-based diets (Omogbenigun et al., 2004).

Table 2. Effects of dietary carbohydrases on growth performance in early finishing pigs $^{1)}$

\begin{tabular}{lrrrc}
\hline Item & \multicolumn{1}{c}{ CON } & \multicolumn{1}{c}{ MIX } & MAN & SE $^{2}$ \\
\hline \hline ADG, g & $806^{\mathrm{b}}$ & $889^{\mathrm{a}}$ & $837^{\mathrm{ab}}$ & 25 \\
ADFI, g & 2,145 & 2,183 & 2,185 & 59 \\
G:F & 0.376 & 0.407 & 0.383 & 0.01 \\
\hline
\end{tabular}

${ }^{1)}$ Abbreviation: CON, basal diet; MIX, CON $+0.05 \%$ mixture with $\alpha$-galactosidase and $\beta$-mannanase; $\mathrm{MAN}, \mathrm{CON}+0.05 \% \quad \beta$ mannanase;

${ }^{2)}$ Standard error.

${ }^{\mathrm{a}, \mathrm{b}}$ Means in the same row with different superscripts differ $(p<0.05)$.

\section{Nutrient digestibility}

Table 3 shows the effects of dietary carbohydrate on nutrient digestibility in early finishing pigs. Apparent total tract digestibility (ATTD) of dry matter(DM) and energy (E) in MIX increased $(p<0.05)$ when compared to $\mathrm{CON}$ and MAN. The ATTD of nitrogen $(N)$ in MIX was higher $(p<0.05)$ than in CON.

Emiola et al. (2009) previously reported that multi carbohydrase enzyme supplementation improved $\mathrm{N}$ and GE digestibility. Additionally, Shim et al. (2003) showed that complex enzyme addition improved energy digestibility. Research with poultry (Cleophas et al., 1995) and pigs (Graham et al., 1988) demonstrated that a combination of different enzyme activities is required for the complete degradation of complex NSP and improved nutrient utilization. The results of the current study showing improvements in the digestibilities of DM, N and $\mathrm{E}$ in diets supplemented with enzyme are consistent with the findings of other researchers (Meng et al., 2002; Omogbenigun et al., 2004).

\section{Blood characteristics}

Table 4 shows the effects of dietary carbohydrate on blood characteristics in early finishing pigs. No significant differences in RBC, WBC, Lymphocyte and $\operatorname{IgG}$ concentration were noted among treatments $(p>0.05)$. Kwon et al. (2000) reported no significant effects of dietary carbohydrate on blood urea nitrogen (BUN) levels. Similarly, Wang et al. (2009) detected no statistically significant differences in the BUN or creatinine values among dietary carbohydrate treatment groups.

Table 3. Effects of dietary carbohydrases on nutrient digestibility in early finishing pigs ${ }^{1)}$

\begin{tabular}{|c|c|c|c|c|}
\hline Item, $\%$ & $\mathrm{CON}$ & MIX & MAN & $\mathrm{SE}^{2)}$ \\
\hline Dry matter & $80.37^{\mathrm{c}}$ & $84.59^{\mathrm{a}}$ & $82.31^{b}$ & 1.69 \\
\hline Nitrogen & $74.54^{\mathrm{b}}$ & $76.57^{\mathrm{a}}$ & $75.34^{\mathrm{ab}}$ & 1.67 \\
\hline Energy & $75.54^{\mathrm{c}}$ & $78.08^{\mathrm{a}}$ & $75.80^{b}$ & 1.81 \\
\hline \multicolumn{5}{|c|}{$\begin{array}{l}\text { 1) Abbreviation: CON, basal diet; MIX, CON }+0.05 \% \text { mixture wi } \\
\alpha \text {-galactosidase and } \beta \text {-mannanase; MAN, CON }+0.05 \% \\
\text { mannanase; } \\
{ }^{2)} \text { Standard error. } \\
\text { a,b,c } \text { Means in the same row with different superscripts differ }(p<0.05) \text {, }\end{array}$} \\
\hline
\end{tabular}


Kim et al.; Carbohydrases in Early Finishing Pigs

Table 4. Effects of dietary carbohydrases on blood characteristics in early finishing pigs ${ }^{1)}$

\begin{tabular}{|c|c|c|c|c|}
\hline Item & $\mathrm{CON}$ & MIX & MAN & $\mathrm{SE}^{2)}$ \\
\hline \multicolumn{5}{|c|}{ RBC, $10^{6} / \mu \mathrm{l}$} \\
\hline Initial & 6.5 & 6.8 & 6.7 & 0.3 \\
\hline Final & 6.3 & 6.7 & 6.6 & 0.2 \\
\hline \multicolumn{5}{|c|}{$\mathrm{WBC}, 10^{3} / \mathrm{ul}$} \\
\hline Initial & 17.4 & 17.5 & 17.6 & 1.6 \\
\hline Final & 16.3 & 16.5 & 17.7 & 0.9 \\
\hline \multicolumn{5}{|c|}{ Lymphocyte, \% } \\
\hline Initial & 43.1 & 45.1 & 43.4 & 3.9 \\
\hline Final & 50.4 & 52.8 & 51.9 & 3.8 \\
\hline \multicolumn{5}{|l|}{$\mathrm{IgG}, \mathrm{mg} / \mathrm{dl}$} \\
\hline Initial & 912 & 924 & 935 & 50.9 \\
\hline Final & 978 & 980 & 976 & 78.8 \\
\hline \multicolumn{5}{|c|}{$\begin{array}{l}\text { 1) Abbreviation: } \mathrm{CON} \text {, basal diet; MIX, } \mathrm{CON}+0.05 \% \text { mixture wit } \\
\text { a-galactosidase and } \beta \text {-mannanase; } \mathrm{MAN}, \mathrm{CON}+0.05 \% \\
\text { mannanase. }\end{array}$} \\
\hline 2) Standard & & & & \\
\hline
\end{tabular}

\section{CONCLUSION}

The results of this study suggest that the addition of a dietary carbohydrate mixture (a-galactosidase and $\beta$-mannanase $0.05 \%)$ could improve growth performance and nutrient digestibility of finishing pigs.

\section{ACKNOWLEDGMENT}

This work was carried out with the support of the Cooperative Research Program for Agriculture Science \& Technology Development (No. 009410 and PJ008494 of 15G Agenda), Rural Development Administration, South Korea.

\section{REFERENCES}

AOAC. 1995. Official Methods of Analysis (16th Ed.). Association of Official Analytical Chemists, Washington, D.C.

Bach Knudsen, K. E. 1997. Carbohydrate and lignin contents of plant material used in animal feeding. Anim. Feed Sci. Technol. 67:319-338.

Bedford, M. R. 1995. Mechanism of action and potential environmental benefits from the use of feed enzymes. Anim. Feed Sci. Technol. 53:145-155.

Blackburn, N. A. and Johnson, I. T. 1981. The effect of guar gum on the viscosity of the gastrointestinal contents and on glucose uptake from the perfused jejunum in the rat. Br. J. Nutr.
46:239-246.

Burnett, G. S. 1966. Studies of viscosity as the probable factor involved in the improvement of certain barely for chicken by enzyme supplementation. Brit. Poult. Sci. 7:55-75.

Chesson, A. 1987. Supplementary enzymes to improve the utilization of pig and poultry diets. In: Haresign, W., Cole, D. J. A. (Eds.), Recent Advances in Animal Nutrition. Butterworts, London, pp. 71-89.

Cleophas, G. M. L., Van Hartngsveldt, W., Somers, W. A. C. and Van Der Lugt, J. P. K. 1995. Enzymes can play an important role in poultry nutrition. World Poult.-Misset 4:12-15.

Duncan, D. B. 1955. Multiple range and multiple F. tests. Biometrics. 11:1.

Edwards, C. A., Johnson, I. T. and Read, N. W. 1988. Do viscous polysaccharides slow absorption by inhibiting diffusion or convection. Eur. J. Clin. Nutr. 42:307-312.

Emiola, I. A., Opapeju, F. O., Slominski, B. A. and Nyachoti, C. M. 2009. Growth performance and nutrient digestibility in pigs fed wheat distillers dried grainswith solubles-based diets supplemented with a multicarbohydrase enzyme. J. Anim. Sci. 87:2315-2322.

Graham, H., Lowgren, W., Petterson, D. and Aman, P. 1988. Effect of enzyme supplementation on digestion of a barley/ pollardbased pig diet. Nutr. Rep. Int. 38:1073-1079.

Högberg, A. and Lindberg, J. E. 2004. Influence of cereal nonstarch polysaccharides and enzyme supplementation on digestion site and gut environment in weaned piglets. Anim. Feed Sci. Technol. 116:113-128.

Hong, J. W. and Kim, I. H. 2001. Recent in the use of enzymes for environment-friendly swine diets. Korean J. Org. Agric. 9:55-67.

Jørgensen, H., Zhao, X. Q. and Eggum, B. O. 1996. The influence of dietary fibre and environmental temperature on the development of the gastrointestinal tract, digestibility, degree of fermentation in the hind-gut and energy metabolism in pigs. Br. J. Nutr. 75:365-378.

Kass, M. L., Van Soest, P. J., Pond, W. G., Lewis, B. and McDowell, R. E. 1980. Utilization of dietary fiber from alfalfa by growing swine. 1. Apparent digestibility of diet components in specific segments of the gastrointestinal tract. J. Anim. Sci. 50:175-191.

Kwon, O. S., Kim, I. H., Hong, J. W., Hong, E. C. and Lee, S. H. 2000. Effects of high-low nutrient density diet on performance in growing-finishing pigs. Kor. J. Anim. Sci. 42(5):571-578.

McCracken, K. J., Bedford, M. R. and Stewart, R. A. 2001. Effect 
of variety, the $1 \mathrm{~B} / 1 \mathrm{R}$ translocation and xylanase supplementation on nutritive value of wheat for broilers. Brit. Poult. Sci. 42:638-642.

McDonald, D. E., Pethick, D. W., Pluske, J. R. and Hampson, D. J. 1999. Adverse effects of soluble non-starch polysaccharides (guar gum) on piglet growth and experimental colibacillosis immediately after weaning. Res. Vet. Sci. 67:245-250.

Meng, X. F., Omogbenigun, F. O., Nyachoti, C. M. and Slominski, B. A. 2002. Degradation of cell wall polysaccharides by combination of carbohydrase enzymes and their effect on nutrient utilization and broiler chicken performance. Poult. Sci. 84:37-47.

NRC. 1998. Nutrient Requirements of domestic animals, No. 2. Nutrient requirements of swine. Ninth revised edition. National Academy of Science. Washington. D. C.

Omogbenigun, F. O., Nyachoti, C. M. and Slominski. B. A. 2004. Dietary supplementation with multienzyme preparations improves nutrient utilization and growth performance in weaned pigs. J. Anim. Sci. 82:1053-1061.

Rainbrid, A. L., Low, A. G. and Zebrowska, T. 1984. Effect of guar gum on glucose and water absorption from isolated loops of jejunum in conscious ggrowing pigs. Br. J. Nutr. 52:489-498.

SAS. 1996. SAS/STAT user's guide: Version 6, 11th ed, SAS Institute Inc., Cavy, NC.

Shim, Y. H., Chae, B. J. and Lee, J. H. 2003. Effect of dietary carbohydrase enzyme complex and microbial phytase supplementation on productivity and nutrient digestibility in growing pigs. Kor. J. Anim. Sci. and Technol. 45(4):569-576.
Simon, O. 1998. The mode of action of NSP hydrolyzing enzymes in the gastrointestinal tract. J. Anim. Feed Sci. 7:115-123.

Vahjen, W., Glaser, K., Schafer, K. and Simon, O. 1998. Influence of xylanase-supplemented feed on the development of selected bacterial groups in the intestinal tract of broiler chicks. J. Agric. Sci. 130:489-500.

Van Kessel, A. G., Drew, M. D. Patience, J. F. and Zijlstra, R. T. 2006. Effect of dietary flaxseed, flux hulls or linseed oil on intestinal microbiota and growth performance in weaned pigs. Abstr. 291. Midwestern Section ASAS and Midwest Branch ADSA 2006 Meeting, Des Moines, IA.

Wang. J. P., Hong, S. M., Yan, L., Yoo, J. S., Lee, J. H., Jang, H. D., Kim, H. J. and Kim, I. H. 2009. Effect of single or carbohydrases cocktail in low-nutrient-density diets on growth performance, nutrient digestibility, blood characteristics, and carcass traits in growing-finishing pigs. Livest. Sci. 126:215220.

White, W. B. 1981. An instrument suitable for viscosity determination of chick intestinal fluid. Poult. Sci. 60:10171021.

Williams, C. H., David, D. J. and Iismaa, O. 1962. The determination of chromic oxide in fecal samples by atomic absorption spectroscopy. J. Agric. Sci. 59:381-385.

Zijlstra, R. T., Li, S., Owusu-Asiedu, A., Simmins, P. H. and Patience, J. F. 2004. Effect of carbohydrase supplementation of wheat- and canola-meal-based diets on growth performance and nutrient digestibility in group-housed weaned pigs. Can. J. Anim. Sci. 84:689-695.

(Received May 16, 2013; Accepted Jul. 11, 2013) 